\title{
Utilization of a novel feedstuff: effects of additives on the fermentation characteristics, chemical composition and in vitro digestibility of tetraploid black locust (Robinia pseudoacacia) silage
}

\section{Zhihao Dong ${ }^{1}$ () Junfeng Li ${ }^{1}$ [1] Lei Chen ${ }^{1}$ Siran Wang ${ }^{1}$ Tao Shao $^{1^{*}}$ (])}

${ }^{1}$ Institute of Ensiling and Processing of Grass, College of Agro-grassland Science, Nanjing Agricultural University (NAU), 210095, Nanjing Shi, Jiangsu Sheng, China. E-mail: taoshaolan@163.com. "Corresponding author.

ABSTRACT: This study was conducted to evaluate the effects of additives on the fermentation characteristics, chemical composition and in vitro digestibility of tetraploid black locust (TBL). The TBL leaves silage was either untreated (control) or treated with $1 \times 10^{6} \mathrm{cfu} / \mathrm{g} F M$ Lactobacillus plantarum (L), $1 \%$ glucose $(G), 3 \%$ molasses $(M)$, a combination of $1 \%$ glucose and Lactobacillus plantarum $(L+G)$, or a combination of $3 \%$ molasses and Lactobacillus plantarum $(L+M)$. Fermentation quality, chemical composition and nutrient digestibility were then analyzed. Ethanol and acetic acid concentrations were the dominant fermentation products in all silages except $L+M$ silage. The $L, G$ and $L+G$ treatments failed to influence the fermentation. The $M$ treatment increased $(P<0.05)$ the lactic acid concentration and lowered $(P<0.05)$ the $\mathrm{pH}$ when compared with control silage. The best fermentation properties were observed in $L+M$ silage, as indicated by the dominance of lactic acid over ethanol in fermentation products. The $M$ and $L+M$ silages exhibited higher $(P<0.05)$ dry matter, and $M$ silage showed higher residual water-soluble carbohydrates than the control. Ensiling increased $(P<0.05)$ the in vitro dry matter, neutral detergent fiber and acid detergent fiber degradability of TBL. Among the silages, M silage had the highest levels of dry matter, neutral detergent fiber and acid detergent fiber degradability. The obtained results suggested that application of lactic acid bacteria together with $3 \%$ molasses could be an effective strategy to prevent the occurrence of ethanol fermentation and improve fermentation quality of TBL silage; addition of fermentable sugars to TBL improves nutrient availability to ruminants.

Key words: additives, fermentation quality, in vitro digestibility, chemical composition, tetraploid black locust.

Utilização de um novo alimento: efeitos de aditivos nas características de fermentação, composição química e digestibilidade in vitro da silagem de gafanhoto negro

tetraplóide (Robinia pseudoacacia)

RESUMO: Este estudo foi conduzido para avaliar os efeitos de aditivos nas características de fermentação, composição química e digestibilidade in vitro do gafanhoto preto tetraplóide (TBL). A silagem de folhas TBL não foi tratada (controle) ou foi tratada com $1 \times 106$ ufc I $\mathrm{g}$ FM Lactobacillus plantarum (L), $1 \%$ glicose (G), $3 \%$ melaço (M), uma combinação de $1 \%$ glicose e Lactobacillus plantarum $(L+G)$, ou uma combinação de $3 \%$ de melaço e Lactobacillus plantarum $(L+M)$. A qualidade da fermentação, a composição química e a digestibilidade dos nutrientes foram analisadas. As concentrações de etanol e ácido acético foram os produtos de fermentação dominantes em todas as silagens, com exceção da silagem $L+M$. Os tratamentos $L, G$ e $L+G$ não influenciaram na fermentação. $O$ tratamento com $M$ aumentou $(P<0,05)$ a concentração de ácido láctico e diminuiu $(P<0,05)$ o $\mathrm{pH}$, quando comparado com a silagem controle. As melhores propriedades de fermentação foram observadas na silagem $L+M$, como indicado pela dominância do ácido lático sobre o etanol nos produtos de fermentação. As silagens $M$ e $L+M$ apresentaram maior teor de matéria seca $(P<0,05)$, e a silagem $M$ apresentou maior carboidrato solúvel em água residual que o controle. A ensilagem aumentou $(P<0,05)$ a matéria seca in vitro, a fibra em detergente neutro e a degradabilidade da fibra em detergente ácido de TBL. Entre as silagens, a silagem M apresentou os maiores teores de matéria seca, fibra em detergente neutro e degradabilidade da fibra em detergente ácido. Os resultados obtidos sugerem que a aplicação de bactérias lácticas em conjunto com 3\% de melaço pode ser uma estratégia eficaz para evitar a ocorrência de fermentação alcoólica e melhorar a qualidade da fermentação da silagem $T B L$. A adição de açúcares fermentáveis à TBL aumenta a disponibilidade de nutrientes para ruminantes.

Palavras-chave: Aditivos, qualidade de fermentação, digestibilidade in vitro, composição química, gafanhoto preto tetraplóide.

\section{INTRODUCTION}

The rapid development of China's economy has triggered increased demand for animal products from consumers. One challenge for further improvement of animal products has been the lack of adequate and high-quality green fodder. Exploring novel feed resources capable of replacing regular poor-quality fodder is important to alleviation of this constraint.

The tetraploid black locust (Robinia pseudoacacia, TBL), a polyploid woody plant bred through artificial doubling of the chromosome of the diploid R. pseudoacacia, was introduced to China in 
1997. There are five TBL clones, two that are used for fodder and another three that are used for timber production (ZHANG et al., 2010). The fodder-use TBL clones grow faster and have denser branches with broader leaves than the diploid species (MENG et al., 2016). In addition, many advantages such as high biomass, few inputs for cultivation, ease of harvesting and processing and high nutritive value make TBL a potent new ideal resource for sustainable forage. Over the past two decades, TBL has been widely planted in China and its leaves have been utilized as a promising protein feed for ruminants. Despite having attracted a great deal of attention, efficient utilization of this woody forage is still in the early stages (ZHANG et al., 2010), and there remains a need for identification of safe and efficient methods of storage to resolve problems regarding seasonal availability.

Based on economics and practical feasibility, ensiling might be the best option for TBL fodder storage, especially in rainy regions. However, black locust, as a species of Leguminosae family, is generally low in soluble carbohydrates content, which could be a disadvantage for extensive lactic fermentation. Furthermore, epiphytic lactic acid bacteria (LAB) play an important role in silage fermentation. Under natural circumstances, the population of LAB is usually low and variable with standing crops (GUO et al., 2014). In this regard, it is recommended that additives should be used for TBL silage to ensure satisfactory quality.

Inoculants containing homo fermentative

LAB have been widely explored to provide sufficient LAB to warrant rapid and intensive fermentation (LI et al., 2018). Molasses, a by-product of the sugarcane and sugar-beet industries, has been extensively used as a fermentation stimulant because of its abundant sucrose content (LI et al., 2014). Glucose is a direct substrate that is easily used by LAB (SHAO et al., 2004). Numerous studies have shown that the addition of these additives can positively influence fermentation quality and feed nutritive value of some conventional ensilage materials, such as alfalfa (FILYA et al., 2007; WU \& NISHINO, 2016). However, as the effectiveness of an additive may vary greatly among ensilage materials, few studies have been conducted to systematically examine their suitability for TBL silage. Therefore, the current study was conducted to investigate effects of adding lactic acid bacteria, glucose and molasses on the fermentation characteristics, chemical composition and in vitro digestibility of TBL silage.

\section{MATERIALS AND METHODS}

\section{Ensilage material}

Tetraploid black locust was planted in a field of Lvjiaxi company in Shitai, Anhui Province, China $\left(117^{\circ} 12^{\prime} \mathrm{E}, 29^{\circ} 59^{\prime} \mathrm{N}\right)$. The entire plant was harvested when it reached approximately $120 \mathrm{~cm}$ in height. The leaving stubble was at $20 \mathrm{~cm}$ above soil level. Leaves and stems were separated using a separator machine, after which the leaves were transported to laboratory and chopped to a length of 2-3 cm using a forage chopper. The TBL leaves used had a dry matter content of $448 \mathrm{~g} / \mathrm{kg}$ fresh matter. Crude protein, water soluble-carbohydrate, neutral detergent fiber and acid detergent fiber contents of TBL were $163,63.9,525$ and $355 \mathrm{~g} / \mathrm{kg}$ dry matter, respectively and the TBL buffering capacity was 478 $\mathrm{mE} / \mathrm{kg}$ dry matter. The LAB, aerobic bacteria and yeast counts were 4.73, 6.36 and $6.44 \mathrm{log} \mathrm{cfu} / \mathrm{g}$ fresh matter, respectively.

\section{Experimental design and silage preparation}

Chopped TBL leaves were thoroughly mixed and then assigned to one of the following treatments: (1) control (without additive); (2) G (glucose); (3) M (molasses); (4) LAB inoculant; (5) combination of glucose and LAB; or (6) combination of molasses and LAB. The application rates of glucose and molasses in this study were $1 \%$ and $3 \%$, respectively, based on the fresh matter. The LAB inoculant used in the latter three treatments was supplied by Ecosyl Products Ltd., Stokesley, North Yorkshire, UK, and mainly consisted of Lactobacillus plantarum. The application rate was $1.0 \times 10^{6}$ colony forming units (cfu)/g of FM in accordance with the manufacturer's specifications. For the preparation of each silo, approximately $620 \mathrm{~g}$ of plant material was packed into a laboratory silo (polyethylene bottle, 1 L capacity) and manually compacted with uniform intensity at $278 \mathrm{~kg}$ dry matter $/ \mathrm{m}^{3}$. There were five silos prepared for each treatment. After being sealed with plastic caps and adhesive tape, silos were stored at ambient temperature $\left(18{ }^{\circ} \mathrm{C}-22{ }^{\circ} \mathrm{C}\right)$ in the laboratory for 60 days. Upon opening, the silages were transferred from the silos to plastic boxes, after which they were mixed and subsamples were taken for chemical and microbial analyses.

\section{Chemical and microbial analyses}

The fresh material and silages were divided into three subsamples. First subsample $(0.5$ $\mathrm{kg}$ ) was oven-dried at $60{ }^{\circ} \mathrm{C}$ for $48 \mathrm{~h}$ to constant weight, then air equilibrated. The dried fresh material 
and silage samples were analyzed for dry matter (934.01) and crude protein (984.13) content using the AOAC method (1984). Water soluble-carbohydrates were quantified as described by DONG et al. (2017). Neutral detergent fibers (with sodium sulfite and heat stable $\alpha$-amylase) and acid detergent fibers were sequentially analyzed following the procedure described by VAN SOEST et al. (1991).

The second subsample (35 g) was extracted in $70 \mathrm{ml}$ of deionized water at $4^{\circ} \mathrm{C}$ for $24 \mathrm{~h}$ to obtain cold extract, which was used to analyze the silage fermentation parameters as described by CHEN et al. (2015). The $\mathrm{pH}$ of the water extract was measured with an electrode $\mathrm{pH}$ meter (HANNA pH 211, Hanna Instruments, Italy). Ammonia nitrogen was measured using the method described by ZHNAG et al. (2015) and results were expressed as $\mathrm{g} / \mathrm{kg}$ total nitrogen. The content of ethanol and organic acids including lactic, acetic, propionic and butyric acid were quantified in the filtrates, using high-performance liquid chromatography (Carbomix ${ }^{\circledR} \mathrm{H}-\mathrm{NP} 5$ column, $55^{\circ} \mathrm{C}$, $\left.2.5 \mathrm{mM} \mathrm{H}_{2} \mathrm{SO}_{4}, 0.5 \mathrm{ml}^{-1} \mathrm{~min}\right)$ in accordance with the method described by YUAN et al. (2017).

To evaluate the microbial populations, the remaining subsamples (10 g) were tenfold serially diluted to optimal ranges with sterilized saline solution $(0.85 \% \mathrm{NaCl})$. The LAB was then counted on de Man, Rogosa and Sharpe agar medium after anaerobic incubation at $37^{\circ} \mathrm{C}$ for 3 days. Yeasts and aerobic bacteria were enumerated on potato dextrose agar and nutrient agar medium, respectively, after incubation at $37^{\circ} \mathrm{C}$ for 2 days. All microbiological data were $\log 10$ transformed.

\section{In vitro digestibility measurements}

Ground samples were put into filter bags (F57; ANKOM Technology, Macedon, USA). Bags were heat-sealed and transported to $130 \mathrm{~mL}$ serum bottles. Rumen fluid was then collected from four Boer male goats that had been fed a diet that contained $50 \%$ roughage and $50 \%$ concentrates plus supplemental vitamins and minerals. The rumen fluid was then strained through four layers of cheesecloth at $39{ }^{\circ} \mathrm{C}$ under $\mathrm{CO}_{2}$, after which it was mixed with $1: 2 \quad(\mathrm{v} / \mathrm{v})$ buffer solution prepared as described by MENKE (1988). Next, $60 \mathrm{ml}$ of the mixture was placed in each serum bottle and subsequently incubated in a water bath at $39^{\circ} \mathrm{C}$ under $\mathrm{CO}_{2}$. After $72 \mathrm{~h}$ of incubation, samples were removed from the serum bottles and then gently rinsed with cold tap water. Bags were then weighed to determine the in vitro dry matter digestibility after being dried in an oven at $65^{\circ} \mathrm{C}$ for $48 \mathrm{~h}$. The in vitro neutral detergent fiber and acid detergent fiber degradability were determined from losses in the neutral detergent fiber or acid detergent fiber degradability during the in vitro digestion process.

\section{Statistical analysis}

All statistical analyses were performed using the general linear model (GLM) procedure of the Statistical Analysis System (SAS Institute Inc., Cary, USA). Data describing the chemical and microbiological compositions of the ensiled forage were subjected to one-way analysis of variance (ANOVA). Tukey's multiple comparison was used for the means separation. A $P<0.05$ was considered to indicate statistical significance.

\section{RESULTS AND DICUSSION}

\section{Effects of additives on the fermentation characteristics of TBL silage}

Silage quality is dependent on rapid LAB multiplication during early stages of ensiling. Intense lactic fermentation reduces $\mathrm{pH}$, inhibits growth of undesirable bacteria and consequently minimizes nutrition losses. A satisfactory number of epiphytic LAB for quality silage is $>5 \log 10 \mathrm{cfu} / \mathrm{g}$ fresh matter and the content of water-soluble carbohydrates should be $>70 \mathrm{~g} / \mathrm{kg}$ dry matter (CHEN et al., 2015). The LAB number and water-soluble carbohydrate content of TBL in this study failed to meet the criteria, indicating the need for additives to improve fermentation.

In the present experiment, control silage exhibited high $\mathrm{pH}$ (5.66) and an extremely low lactic acid concentration (3.32 g/kg of dry matter), which are typical features of poor fermentation quality (Table 1). Additionally, the ethanol concentration was reported to be great $(32.6 \mathrm{~g} / \mathrm{kg}$ dry matter), indicating intense ethanol fermentation. Ethanol fermentation is undesirable because it contributes little to silage acidification and causes high dry matter losses (LI \& NISHINO, 2011). Furthermore, high accumulation of ethanol in silage may lead to poor acceptance by animals (RANDBY et al., 1999). It has been reported that the predominance of ethanol fermentation over lactic fermentation frequently occurs in high dry matter silages without additives (DRIEHUIS \& WIKSELAAR, 2000). One possible explanation for the development of TBL into ethanol silage may be low water activity. WHITER \& KUNG (2001) reported that only $10 \%$ of the total population of epiphytic LAB on forages could grow on a modified, selective agar with a water activity of 0.952 (corresponding to forage with a dry matter content of $50 \%$ ), suggesting that 
Table 1 - Effects of additives on the fermentation characteristics ( $\mathrm{g} \mathrm{kg}^{-1}$ of dry matter, unless stated otherwise) and chemical composition of tetraploid black locust silage.

\begin{tabular}{|c|c|c|c|c|c|c|c|}
\hline Item $^{1}$ & Control & G & M & $\mathrm{L}$ & $\mathrm{L}+\mathrm{G}$ & $\mathrm{L}+\mathrm{M}$ & $\mathrm{SEM}^{3}$ \\
\hline $\mathrm{pH}$ & $5.79^{\mathrm{a}}$ & $5.76^{\mathrm{a}}$ & $5.59^{\mathrm{b}}$ & $5.72^{\mathrm{a}}$ & $5.73^{\mathrm{a}}$ & $4.78^{\mathrm{c}}$ & 0.02 \\
\hline Lactic acid & $3.32^{\mathrm{c}}$ & $4.12^{\mathrm{c}}$ & $9.57^{b}$ & $4.59^{\mathrm{c}}$ & $6.70^{\mathrm{bc}}$ & $38.6^{\mathrm{a}}$ & 0.33 \\
\hline Acetic acid & $16.8^{\mathrm{c}}$ & $19.5^{\mathrm{bc}}$ & $23.6^{\mathrm{ab}}$ & $26.1^{\mathrm{ab}}$ & $28.8^{\mathrm{a}}$ & $14.6^{\mathrm{c}}$ & 1.57 \\
\hline Propionic acid & $0.76^{\mathrm{ab}}$ & $0.83^{\mathrm{a}}$ & $0.83^{\mathrm{a}}$ & $0.66^{\mathrm{bc}}$ & $0.70^{\mathrm{abc}}$ & $0.56^{\mathrm{c}}$ & 0.01 \\
\hline Butyric acid & $0.78^{\mathrm{ab}}$ & $1.11^{\mathrm{a}}$ & $0.80^{\mathrm{ab}}$ & $0.66^{\mathrm{b}}$ & $0.72^{\mathrm{ab}}$ & $0.57^{b}$ & 0.08 \\
\hline Ethanol & $32.6^{\mathrm{ab}}$ & $30.7^{\mathrm{ab}}$ & $27.3^{\mathrm{b}}$ & $34.1^{\mathrm{a}}$ & $31.3^{\mathrm{ab}}$ & $7.80^{\mathrm{c}}$ & 0.87 \\
\hline TFP & $54.3^{\mathrm{b}}$ & $56.3^{\mathrm{b}}$ & $62.1^{\mathrm{ab}}$ & $66.1^{\mathrm{a}}$ & $68.2^{\mathrm{a}}$ & $62.1^{\mathrm{ab}}$ & 2.43 \\
\hline Lactic acid/TFP (\%) & $6.12^{\mathrm{c}}$ & $7.32^{\mathrm{c}}$ & $15.4^{\mathrm{bc}}$ & $6.94^{\mathrm{c}}$ & $9.82^{\mathrm{c}}$ & $62.1^{\mathrm{a}}$ & 1.51 \\
\hline Ethanol/TFP (\%) & $0.60^{\mathrm{a}}$ & $0.55^{\mathrm{a}}$ & $0.44^{\mathrm{a}}$ & $0.46^{\mathrm{a}}$ & $0.46^{\mathrm{a}}$ & $0.12^{\mathrm{b}}$ & 0.01 \\
\hline $\mathrm{NH}_{3}-\mathrm{N}\left(\mathrm{g} \mathrm{kg}^{-1}\right.$ of $\left.\mathrm{TN}\right)$ & 60.5 & 58.3 & 60.1 & 54.8 & 56.4 & 54.5 & 2.15 \\
\hline
\end{tabular}

${ }^{1}$ TFP, total fermentation products (lactic, acetic, propionic, butyric acids and ethanol); $\mathrm{NH}_{3}-\mathrm{N}$, ammonia-N; TN, total nitrogen.

${ }^{2} \mathrm{G}$, glucose; M, molasses; L, lactic acid bacteria inoculant (Lactobacillus plantarum); L+G, combination of L and G; L+M, combination of $\mathrm{L}$ and $\mathrm{M}$.

${ }^{3}$ SEM, standard error of the mean. Within a row, means with different letters $(\mathrm{a}-\mathrm{d})$ differ significantly $(P<0.05, \mathrm{n}=5)$.

epiphytic LAB is not very osmotolerant. In contrast, DRIEHUIS \& WIKSELAAR (2000) showed that ethanol-producing microorganisms were more osmotolerant than epiphytic LAB and able to thrive on silages with low water activity. Therefore, these findings indicated that epiphytic LAB flora were restricted to a greater extent than ethanol-producing microorganisms, thereby increasing the chance of ethanol-producing microorganisms outgrowing the epiphytic LAB. Concentrations of butyric acid $(<2 \mathrm{~g} / \mathrm{kg}$ dry matter) and ammonia $\mathrm{N}(<100 \mathrm{~g} / \mathrm{kg}$ total nitrogen) were low in ensiled TBL (Table 2), indicating that there were no large concentrations of clostridia or other protein-degrading spoilage organisms, despite the high $\mathrm{pH}$ of the TBL silage. The suppression of these spoilage organisms might have been because of a combined effect of high ethanol concentration and low water activity.

DRIHUIS (2000) previously showed that the addition of a silage inoculant containing Lactobacillus plantarum strains to high dry matter grass silage improved lactic fermentation and successfully prevented ethanol fermentation. However, in the present study, LAB inoculation alone did not alter the fermentation to a more lactic pattern, despite Lactobacillus plantarum having high osmotolerance

Table 2 - Effects of additives on the chemical composition $\left(\mathrm{g} \mathrm{kg}^{-1}\right.$ of dry matter, unless stated otherwise) of tetraploid black locust silage.

\begin{tabular}{|c|c|c|c|c|c|c|c|}
\hline & --------- & ------- & -------T & ent ${ }^{1}---$ & ----- & ------- & \\
\hline Item & Control & G & M & $\mathrm{L}$ & $\mathrm{L}+\mathrm{G}$ & $\mathrm{L}+\mathrm{M}$ & SEM $^{2}$ \\
\hline Dry matter ( $\mathrm{g} \mathrm{kg}^{-1}$ of fresh matter) & $408^{\mathrm{bc}}$ & $412^{\text {cd }}$ & $424^{\mathrm{a}}$ & $404^{\mathrm{c}}$ & $416^{\mathrm{b}}$ & $430^{\mathrm{a}}$ & 4.30 \\
\hline Water-soluble carbohydrate & $32.4^{\mathrm{b}}$ & $34.0^{\mathrm{ab}}$ & $41.1^{\mathrm{a}}$ & $30.0^{\mathrm{b}}$ & $29.5^{\mathrm{b}}$ & $27.9^{\mathrm{b}}$ & 1.29 \\
\hline Crude protein & $143^{\mathrm{ab}}$ & $136^{\mathrm{b}}$ & $144^{\mathrm{ab}}$ & $139^{\mathrm{b}}$ & $149^{\mathrm{a}}$ & $147^{\mathrm{ab}}$ & 2.56 \\
\hline Neutral detergent fiber & 452 & 445 & 458 & 408 & 421 & 421 & 8.15 \\
\hline Acid detergent fiber & 309 & 306 & 325 & 277 & 283 & 249 & 5.79 \\
\hline
\end{tabular}

${ }^{1} \mathrm{G}$, glucose; M, molasses; L, lactic acid bacteria inoculant (Lactobacillus plantarum); L+G, combination of L and G; L+M, combination of $\mathrm{L}$ and $\mathrm{M}$.

${ }^{2} \mathrm{SEM}$, standard error of the mean. Within a row, means with different letters (a-d) differ significantly $(P<0.05, \mathrm{n}=5)$. 
(WHITER \& KUNG, 2001). The poor performance of Lactobacillus plantarum was likely related to the low water-soluble carbohydrate concentration of TBL, which was insufficient to sustain an intense lactic fermentation (BAERTSCHE et al., 1986).

The fermentation exhibited positive responses to molasses addition, and adding molasses increased $(P<0.05)$ lactic acid and lowered $(P<0.05)$ $\mathrm{pH}$ relative to the control silage (Table 2). However, lactic acid did not exceed ethanol as the main fermentation product. This might have been because of the lack of effective epiphytic LAB on TBL, which failed to ensure vigorous lactic fermentation. Consistent with our results, many studies have previously reported that the number of LAB present on some standing crops is low and $80 \%$ of isolated colonies were found to be Leuconostoc sp. (CAI, 1999; YUAN et al., 2016). In this study, treatment with $\mathrm{G}$ and $\mathrm{L}+\mathrm{G}$ did not induce any positive responses on fermentation. This might be explained by the fact that the amount of fermentable sugars supplied through glucose addition was not adequate to elicit a significant effect.

Notably, a synergetic effect on fermentation quality was observed when TBL was applied together with Lactobacillus plantarum and molasses, as indicated by the dominance of lactic acid over ethanol in fermentation products in the $\mathrm{P}+\mathrm{M}$ silage (Table 2). The Lactobacillus plantarum used in this study is capable of fermenting a wide variety of substrates and quickly producing large amounts of lactic acid. The effective LAB had adequate substrate, which explained the improved quality of $\mathrm{L}+\mathrm{M}$ silage. Replacement of ethanol by lactic fermentation suggested that application of $\mathrm{LAB}$ inoculant combined with $3 \%$ molasses could be an effective strategy for avoiding ethanol fermentation and improving fermentation quality of TBL silage.

Effects of additives on the chemical composition and in vitro digestibility of TBL silage

Addition of molasses or combined addition of molasses and LAB improved lactic fermentation and reduced dry matter and energy losses during fermentation, accounting for the higher dry matter in the $\mathrm{M}$ and $\mathrm{L}+\mathrm{M}$ silages (Table 2). Residual watersoluble carbohydrate contents were high $(>27 \mathrm{~g} / \mathrm{kg}$ dry matter) in all silages, regardless of treatments. This indicated that fewer fermentable sugars were utilized for microbial fermentation, which might have been a result of the low water activity of TBL silage that restricted the overall fermentation. The M silage contained higher residual water-soluble carbohydrates than the other treated silages and control silage. This was probably a result of the weak efficiency of water-soluble carbohydrate conversion to lactic acid by epiphytic LAB resulting in more water-soluble carbohydrate being retained in $\mathrm{M}$ silages (GUO et al., 2014).

The digestibility parameters of forages are considered to be essential to estimation of their nutritive value to ruminants (Table 3 ). When compared with other forages such as alfalfa, the digestibility of dry matter, neutral detergent fiber and acid detergent fiber in TBL was relatively low (PALMONARI et al., 2014). This was likely because there were more cell-wall structural constituents, including cellulose and lignin, in TBL leaves. The presence of some antinutritional components such as tannins and lectin may also have affected the digestibility parameters in the rumen (BURNER et al., 2008). Several studies have shown that some ruminal bacteria are very sensitive to tannins (MIN et al., 2005), and adding tannins to the diet consistently decrease the growth and protease activity of Butyrivibrio fibrisolvens, Streptococcus bovis and Butyrivibrio proteoclastius isolated from the rumen (VASTA et al., 2010). Considering that TBL contain high amounts of condensed tannins in their leaves (ZHANG et al., 2010), it can be expected that ruminal fermentation would be depressed following consumption of TBL leaves.

Digestibility of dry matter, neutral detergent fiber and acid detergent fiber in all TBL silage samples were markedly increased when compared with that in fresh material (Table 3). This was probably because of a combination of enzymatic and acid hydrolysis of the more digestible cell wall fractions during the ensiling process (XUE et al., 2017). Increases in digestibility parameters indicated that ensiling can be an effective approach to improve the nutritive value of TLB for ruminant feeding.

In general, high residual water-soluble carbohydrates and crude protein concentrations in silages are preferable for rumen microbial degradation during in vitro incubation (WANG et al., 2017); however, other factors such as the balance of dietary energy and protein applied to ruminants can also affect the biodegradability of ruminal microorganisms (SOUSA et al., 2009). The TBL is relatively rich in protein but poor in readily available carbohydrates. In the present study, increased residual water-soluble carbohydrate in $M$ silage resulted in more balanced dietary energy and protein during in vitro incubation, which favored the growth and activity of ruminal microorganisms, explaining the increases in digestibility of molasses-treated silage 
Table 3 - Effects of additives on the in vitro digestibility of fresh and ensiled tetraploid black locust.

\begin{tabular}{|c|c|c|c|c|c|c|c|c|}
\hline & Fresh sample & ---------- & -------- & -----En & sample & ---------- & --------- & \\
\hline Item & & Control & G & M & $\mathrm{L}$ & $\mathrm{L}+\mathrm{G}$ & $\mathrm{L}+\mathrm{M}$ & $\mathrm{SEM}^{2}$ \\
\hline Dry matter $(\%)$ & $41.4^{\mathrm{d}}$ & $52.0^{\mathrm{c}}$ & $54.1^{\mathrm{c}}$ & $60.5^{\mathrm{a}}$ & $52.9^{c}$ & $52.6^{\mathrm{c}}$ & $57.2^{\mathrm{b}}$ & 2.84 \\
\hline Neutral detergent fiber $(\%)$ & $17.4^{\mathrm{c}}$ & $25.2^{\mathrm{b}}$ & $26.9^{\mathrm{b}}$ & $35.0^{\mathrm{a}}$ & $23.4^{\mathrm{b}}$ & $25.0^{\mathrm{b}}$ & $28.0^{\mathrm{ab}}$ & 1.51 \\
\hline Acid detergent fiber $(\%)$ & $9.05^{\mathrm{c}}$ & $19.0^{\mathrm{b}}$ & $18.3^{\mathrm{b}}$ & $26.2^{\mathrm{a}}$ & $16.0^{\mathrm{b}}$ & $16.7^{\mathrm{b}}$ & $21.8^{\mathrm{ab}}$ & 1.02 \\
\hline
\end{tabular}

${ }^{1} \mathrm{G}$, glucose; M, molasses; L, lactic acid bacteria inoculant (Lactobacillus plantarum); $\mathrm{L}+\mathrm{G}$, combination of L and G; L+M, combination of $\mathrm{L}$ and $\mathrm{M}$.

${ }^{2} \mathrm{SEM}$, standard error of the mean. Within a row, means with different letters $(\mathrm{a}-\mathrm{d})$ differ significantly $(P<0.05, \mathrm{n}=5)$.

(Table3). These results indicated that supplementation of TBL with fermentable sugars can improve nutrient availability to ruminants.

In conclusion, the results of this study showed that: (i) ethanol fermentation could easily occur in TBL silage; (ii) combined addition of lactic acid bacteria inoculant and 3\% molasses could prevent the occurrence of ethanol fermentation and improve fermentation quality; (iii) utilization of TBL by ruminal microorganisms in vitro is relatively limited, but it could be improved to some extent by supplementation with fermentable sugar.

\section{ACKNOWLEDGEMENTS}

This work was financially supported by Postgraduate Research \& Practice Innovation Program of Jiangsu Province (KYCX18 0753) and the special project of grass of Tibetan autonomous region for the "13th Five-Year" Plan "technology research and demonstration of high-quality grass product processing”, China (2018ZDKJZC).

\section{DECLARATION OF CONFLICT OF INTERESTS}

The authors declare no conflict of interest. The founding sponsors had no role in the design of the study; in the collection, analyses, or interpretation of data; in the writing of the manuscript, and in the decision to publish the results.

\section{AUTHORS' CONTRIBUTIONS}

ZHD and TS conceived and designed experiments, ZHD performed the experiments, LC and SRW carried out the lab analyses. LC performed statistical analyses of experimental data. ZHD prepared the draft of the manuscript. All authors critically revised the manuscript and approved of the final version.

\section{REFERENCES}

AOAC (ASSOCIATION OF OFFICIAL ANALYTICAL CHEMISTS). Official methods of analysis of the Association of Official Analytical Chemists. 14.ed. Washington: AOAC International, 1984. 1121p.

BAERTSCHE, S, R. et al. Short rotation, hardwood tree biomass as potential ruminant feed-chemical composition, nylon bag ruminal degradation and ensilement of selected species. Journal of Animal Science. v.63, n.6, p.2028-2043, 1986. Available from: <https:// www.researchgate.net/publication/237270590>. Accessed: Jan. 01, 1986. doi: 10.2527/jas1986.6362028x.

BURNER, D. M. et al. Yield components and nutritive value of Robinia pseudoacacia and Albizia julibrissin in Arkansas, USA. Agroforest Systems. v.72, n.1, p.51-62, 2008. Available from: $<$ https://www.researchgate.net/publication/43274200>. Accessed: Oct. 2, 2007. doi: 10.1007/s10457-007-9098-x.

CAI, Y. Identification and characterization of Enterococcus species isolated from forage crops and their influence on silage fermentation. Journal of Dairy Science, v.82, n.11, p.2466-2471, 1999. Available from: <https://www.sciencedirect.com/science/ article/pii/S0022030299754986?via\%3Dihub>. Accessed: Nov.01, 1999. DOI: 10.3168/jds.S0022-0302(99)75498-6.

CHEN, L. et al. The effects of replacement of whole-plant corn with oat and common vetch on the fermentation quality, chemical composition and aerobic stability of total mixed ration silage in Tibet. Animal Science Journal, v.86, n.1, p.69-76, 2015. Available from: < https://onlinelibrary.wiley.com/doi/abs/10.1111/ asj.12245>. Accessed: Apr. 03, 2015. doi: 10.1111/asj.12245.

DONG, Z. et al. Effects of calcium propionate on the fermentation quality and aerobic stability of alfalfa silage. Asian-Austral Journal of Animal Sciences, v.30, n.9, p.1278-1284, 2017. Available from: $<$ https://doi.org/10.5713/ajas.16.0956>. Accessed: Mar. 21, 2017. doi: 10.5713/ajas.16.0956.

DRIEHUIS, F.; VAN WIKSELAAR, P. G. The occurrence and prevention of ethanol fermentation in high dry matter grass silage. Journal of the Science of Food and Agriculture, v.80, n.6, p.711-718. 2000. Available from: <https://www. researchgate.net/publication/229464047>. Accessed: Dec. 6, 1999. doi: 10.1002/(SICI)1097-0010(20000501)80:6<711::AIDJSFA593 $>3.0 . \mathrm{CO} ; 2-6$

FILYA, I. et al. Inoculant effects on alfalfa silage: fermentation products and nutritive value. Journal of Dairy Science, v.90, n.11, p.5108-5114, 2007. Available from: <http://www.sciencedirect.co m\%2Fscience \%2Farticle\%2Fpii\%2FS002203020771980X\&ie= utf8\&sc_us=17812478801612696516>. Accessed: May 2, 2007. doi: $10 . \overline{3} 168 /$ jds.2006-877. 
GUO, G. et al. Effects of fibrolytic enzymes, molasses and lactic acid bacteria on fermentation quality of mixed silage of corn and hulless-barely straw in the Tibetan Plateau. Grassland Science, v.60, n.4, p.240-246, 2014. Available from: <https://www. researchgate.net/publication/265091133> Accessed: May, 20, 2014. doi: $10.1111 /$ grs. 12060 .

LI, J. et al. Characterization of Enterococcus faecalis JF85 and Enterococcus faecium Y83 isolated from Tibetan yak (Bos grunniens) for ensiling Pennisetum sinese. Bioresouce Technology. v.257, p.76-83, 2018. Available from: <https://doi. org/10.1016/j.biortech.2018.02.070>. Accessed: Feb.14, 2018. doi: 10.1016/j.biortech.2018.02.070.

LI, M. et al. Effects of sucrose, glucose, molasses and cellulase on fermentation quality and in vitro gas production of king grass silage. Animal Feed Science and Technology. v.197, p.206-212, 2014. Available from: <http://dx.doi.org/10.1016/j. anifeedsci.2014.06.016>. Accessed: Jun. 29, 2014.

LI, Y. et al. Bacterial and fungal communities of wilted Italian ryegrass silage inoculated with and without Lactobacillus rhamnosus or Lactobacillus buchneri. Letters in Appiled Mirobiology. v.52, n.4, p.314-321, 2011. Available from: <http:// www.ncbi.nlm.nih.gov\%2Fpubmed $\% 2$ F $21204884 \% 2 F \& i e=u t$ f8\&sc_us $=1193702483191805014>$. Accessed: Dec. 22, 2010. doi:10.1111/j.1472-765X.2010.03000.x.

MENG, F. et al. Physiological and proteomic responses to salt stress in chloroplasts of diploid and tetraploid black locust (Robinia pseudoacacia L.). Scientific Reports. v.6, 2016. Available from: $<$ http://www.ncbi.nlm.nih.gov\%2Fpubmed\%2F26975701\&ie =u tf8\&sc us=13735909411062924589>. Accessed: Feb. 07, 2016. doi: $10.1038 /$ srep 23098 .

MENKE, K. Estimation of the energetic feed value obtained from chemical analysis and in vitro gas production using rumen fluid. Animal Research and Development. v. 28, p.7-55, 1988. Available from: <https://www.researchgate.net/publication/286682081>. Accessed: Jan. 1988.

MIN, B. R. Wheat pasture bloat dynamics, in vitro ruminal gas production, and potential bloat mitigation with condensed tannins Journal of Animal Science. v.83, n.6, p.1322-1331, 2005. Available from: <https://www.researchgate.net/publication/7850167>. Accessed: May, 14, 2005. doi: 10.2527/2005.8361322x.

PALMONARI, A. et al. Influence of maturity on alfalfa hay nutritional fractions and indigestible fiber content. Journal of Dairy Science. v.97, n. 12, p.7729-7734, 2014. Available from: <http:// www.ncbi.nlm.nih.gov\%2Fpubmed $\% 2$ F25262189\&ie $=$ utf-8\&sc us $=14123187190078023062>$. Accessed: Aug. 06, 2014. doi: $10.3168 /$ jds.2014-8123.

RANDBY, A. Y. et al. Effect of ethanol in feed on milk flavor and chemical composition. Journal of Animal Science. v.82, n.2 p.420-428, 1999. Available from: <https://www.sciencedirect.com/ science/article/pii/S0022030299752483?via\%3Dihub>. Accessed: Sep. 28, 1998. doi: 10.3168/jds.S0022-0302(99)75248-3.

SHAO, T, et al. Effects of adding glucose, sorbic acid and prefermented juices on the fermentation quality of guineagrass (Panicum maximum Jacq.) silages. Asian-Australasian Journal of Animal Sciences. v.17, n.6, p.808-813, 2004. Available from: $\quad<$ https://www.researchgate.net/publication/263623957>. Accessed: Mar. 02, 2004. doi: 10.5713/ajas.2004.808.

SOUSA, D. et al. Fermentative parameters, microbial protein production, plasma and milk urea concentration and nitrogen balance of milking cows fed maize silage or sugarcane with whole cottonseed. Revista Brasileira De Zootecnia. v.38, n.10, p.20632071, 2009. Available from: <https://www.researchgate.net/ publication/262462414>. Accessed: May 11, 2009.

VAN SOEST, P. J. et al. Methods for dietary fiber, neutral detergent fiber, and nonstarch polysaccharides in relation to animal nutrition. Journal of Dairy Science. v.74, n. 10, p.3583-3597, 1991. Available from: <http://www.ncbi.nlm.nih.gov\%2Fpubmed\%2F1660498\%3 Fdopt\%3DAbstract\&ie=utf-8\&sc_us $=15708666796323421607>$. Accessed: Feb. 06, 1991. doi: 10.3168/jds.S0022-0302(91)78551-2.

VASTA, V. et al. Bacterial and protozoal communities and fatty acid profile in the rumen of sheep fed a diet containing added tannins. Applied and Enviromental Microbiology. v.76, n.8, p.2549-2555, 2010. Available from: <http://www.ncbi.nlm.nih. gov\%2Fpmc\%2Farticles\%2FPMC2849217\%2Fpdf\%2F2583-09. pdf\&ie $=$ utf- $8 \&$ sc us $=1618978937366756788>$. Accessed: Apr. 01, 2010. doi: 10.1128/AEM.02583-09.

WANG, S. et al. Effect of ensiling corn stover with legume herbages in different proportions on fermentation characteristics, nutritive quality and in vitro digestibility on the Tibetan Plateau. Grassland Science. v.63, n.4, p.236-244, 2017. Available from: <https://www. researchgate.net/publication/319465687>. Accessed: May, 12, 2017. doi: $10.1111 /$ grs. 12173 .

WHITER, A.G.; KUNG, Jr. L. The effect of a dry or liquid application of Lactobacillus plantarum MTD1 on the fermentation of alfalfa silage. Journal of Dairy Science. v.84, n.10, p.2195-2202, 2001. Available from: <http://www. ncbi.nlm.nih.gov\%2Fpubmed \%2F $11699451 \&$ ie $=$ utf-8\&sc us $=17315557447086518924>$. Accessed: May, 16, 2001. doi: 10.3168/jds.S0022-0302(01)74666-8.

WU, B; NISHINO, N. Identification and isolation of Lactobacillus fructivorans from wilted alfalfa silage with and without molasses. Appied and Enviromental Microbiology. v.120, n.3, p.543-551, 2016. Available from: <http://www. ncbi.nlm.nih.gov\%2Fpubmed $\% 2$ F26681634\&ie $=$ utf- $8 \&$ sc us $=4328391325757933703>$. Accessed: Dec. 18, 2015. doi: 10.1111/jam.13031

XUE, Y. L. et al. Nutritive value of desert wormwood (Artemisia desertorum Spreng.) silage in mixture with high-moisture maize straw. Grass and Forage Science. v.72, n.1, p.174178, 2017. Available from: <http://www.researchgate.net/ publication/282844557>. Accessed: Jan. 07, 2015. doi: 10.1111/ gfs. 12202 .

YUAN, X. J. et al. Effects of ethanol, molasses and Lactobacillus plantarumon fermentation characteristics and aerobic stability of total mixed ration silages. Grass and Forage Science. v.71, n.2, p.328-338. 2016. Available from: <https://www.researchgate.net/ publication/280874072>. Accessed: Apr. 30, 2015. doi: 10.1111/ gfs. 12180 .

YUAN, X. J. et al. Effects of four short-chain fatty acids or salts on the dynamics of nitrogen transformations and intrinsic protease activity of alfalfa silage. Journal of the Science of Food and Agriculture. v.97, n.9, p.2759-2766. 2017. Available from: $<$ http://www.ncbi.nlm.nih.gov\%2Fpubmed\%2F27754550\&ie=utf $8 \&$ sc_us $=7116262963406034660>$. Accessed: Oct. 18,2016 . doi: $10.1002 /$ jsfa. 8103 .

ZHANG, G. J. et al. Effects of different supplements on tetraploid black locust (Robinia pseudoacacia L.) silage. Forestry Studies in China. v.12, n.4, p.176-183, 2010, Available from: <https:// link.springer.com/article/10.1007/s11632-010-0402-x>. Accessed: Sep. 01, 2010. doi: 10.1007/s11632-010-0402-x. 